\title{
Growth and yielding of peach and nectarine trees after intensive regenerative pruning
}

\author{
Bożena Radajewska, Michat Szklarz \\ Department of Pomology \\ Poznań University of Life Sciences \\ Dąbrowskiego 159, 60-594 Poznań, Poland \\ e-mail: bradajewska@wp.pl
}

Key word s: hard winter, tree crown height, trunk and shoots characteristic

\begin{abstract}
Studies were carried out in the years 2006-2008 in Przybroda near Poznan. The objects of the studies included seven-year-old peach trees of the cultivars 'Harnaś', 'Reliance', 'Vinegold' and 'Early Blaze' nectarine. The trees were strongly damaged by frost during the winter of 2005/2006. In May 2006, intensive regenerative tree pruning was carried out. Two treatments were applied: 1 . The control with no pruning treatment, where only sanitary pruning was performed; 2. Trees were pruned at the height of $1.5 \mathrm{~m}$ and the shoots, which were developing below that height line, were left not pruned. The pruning treatment caused the development of an abundant number of longshoots, which are valuable for fruiting, in the central part of the crowns, with a diameter greater than $0.5 \mathrm{~cm}$ in comparison with the control trees. In the second year after pruning, spring ground frost destroyed the flowers and fruit buds and only single fruits were harvested. In the third year after pruning, the trees bloomed very abundantly and set fruits, therefore thinning was necessary. The yield was high and in most cases, it was equal
\end{abstract}


Peach and nectarine trees after regenerative pruning

independent of the tree pruning method, giving up to $18-19 \mathrm{~kg}$ per tree. Differences occurred only between the particular cultivars where the yield oscillated between 11 and $25 \mathrm{~kg}$ per tree. The best yielding was shown by 'Vinegold' (over $24 \mathrm{~kg}$ ), then 'Harnaś' $(21 \mathrm{~kg}$ ), while the poorest yield was obtained from 'Reliance' (about $11 \mathrm{~kg})$.

\section{INTRODUCTION}

In Poland, every few years hard winters occur and cause great damage to peach orchards. In such situations, the destruction includes not only flower buds but also the wood pulp of the branches, annihilating the total yield, as has happened after the winter of 2005/2006, when the minimum temperature reached $-28.5^{\circ} \mathrm{C}$ (Radajewska and Szklarz 2006). According to many authors (Marini 1984, Dudziński and Hołubowicz 1985, Radajewska 1989, Norton 2002, Morgaś 2006), intensive pruning stimulates the regeneration processes as well as modifies the size of tree crowns, particularly decreasing the excessive tree height. The purpose of the presented studies was the estimation of the intensive pruning effect of peach trees on the regeneration processes, crown reconstruction and yielding.

\section{MATERIAL AND METHODS}

Studies were carried out in the years 2006-2008 in the experimental orchard in Przybroda. The objects of the studies were seven-year old peach trees of 'Harnas' and 'Reliance', non-melting 'Vinegold' clingstone and 'Early Blaze' nectarines. Trees on 'Rakoniewicka Seedling' rootstock with open centre crowns were grown in a spacing of $4.0 \times 2.5 \mathrm{~m}$ in a random block design in six replications (trees). In the rows of trees, there was herbicide fallow, while sward was grown in the inter-rows. Every year, standard fertilization was applied and prophylactic plant protection treatments according to the recommendations for peach orchards were carried out. After the frost damages during the winter period of 2005/2006 (Radajewska and Szklarz 2006), intensive tree pruning was performed at the end of May according to the following assumptions:

1. Control combination - trees were not pruned, only sanitary treatment was carried out as a usual yearly procedure,

2. Trees were pruned at the height of $1.5 \mathrm{~m}$ and shoots developing below that height line were left not pruned (Fig. 1). 


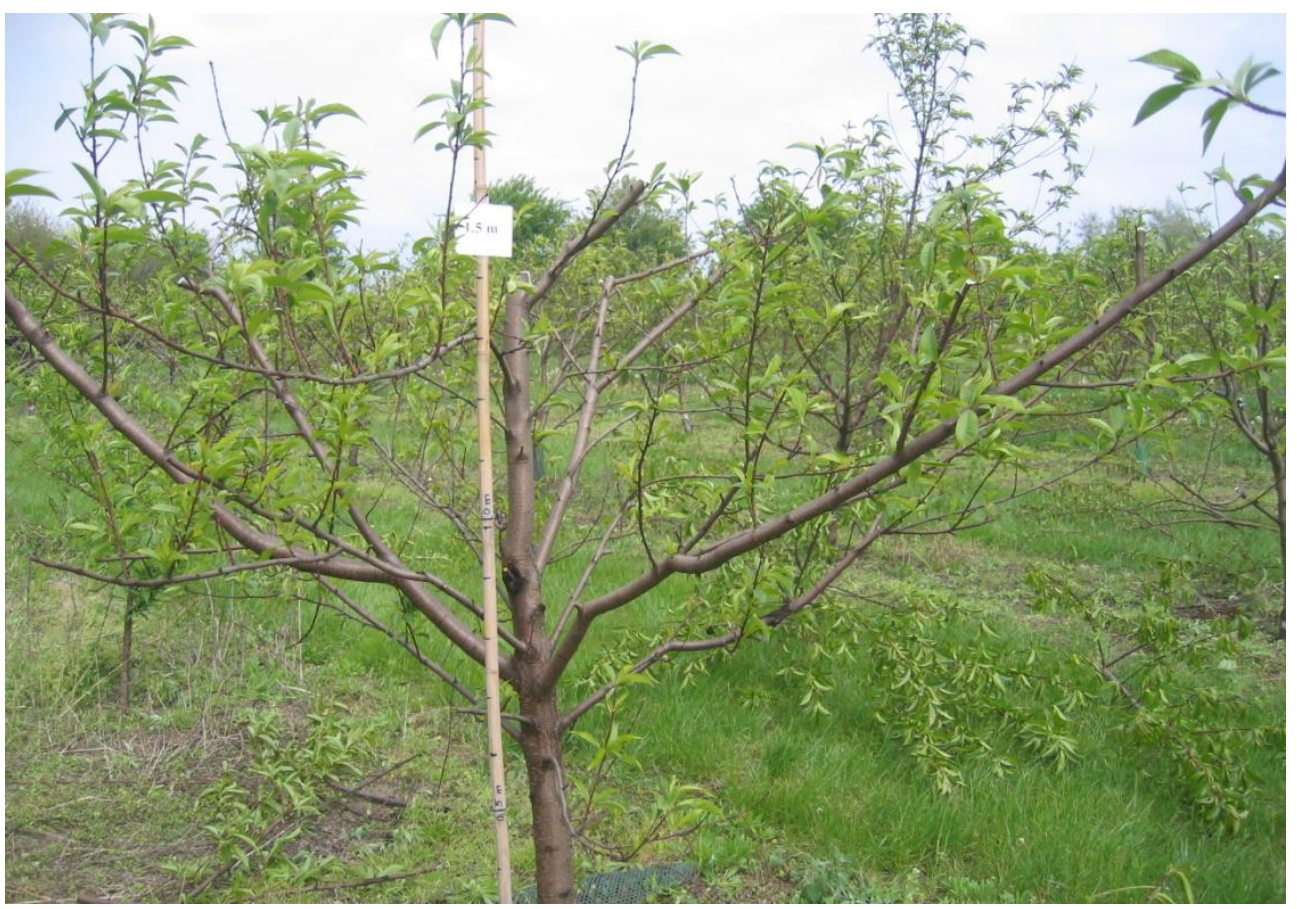

Figure 1. Tree pruned at height of $1.5 \mathrm{~m}$

Directly after pruning, high nitrogen and potassium fertilization was applied in the dose of $\mathrm{N} 100 \mathrm{~kg} \mathrm{ha}^{-1}$ and $\mathrm{K}_{2} \mathrm{O} 150 \mathrm{~kg} \mathrm{ha}^{-1}$. Every year in autumn, tree growth parameters were estimated including tree height, crown projection (quotient of two widths), number of one-year-old longshoots with diameters greater than $0.5 \mathrm{~cm}$ and their mean and total lengths on selected branches in the central part of tree crowns, as well as the tree trunk thickness expressed by the trunk cross-sectional area (TCSA) and its increment. Only the results of tree height measurements after one season after regenerative pruning are presented (autumn 2006). Because sanitary pruning was carried out every year, this is why these results are not presented. The yielding of trees was estimated every year as well.

The obtained results were statistically elaborated by the STAT program of variance analysis for two-factorial experiments. The significance of differences was estimated at the confidence level of $p=0.05$.

\section{RESULTS AND DISCUSSION}

In the year 2006, after tree pruning and abundant fertilization, the non-fruiting trees were growing very intensively. Tree growth estimation showed that the non-pruned 
control trees increased their growth in a significantly lesser degree, but in spite of that, depending on the cultivar, they reached up to $4.0 \mathrm{~m}$ height, while in the case of the pruned trees, although they were growing more intensively, their height was lower by $50-120 \mathrm{~cm}$ than that of the control trees. Observations of the compensation growth of the pruned trees indicated that eventually their growth increments reached up to 1.0-1.2 m. The height of the intensively growing 'Harnas' peaches was a distinguishing one. The pruning of trees caused in the majority of cultivars a decrease of crown projection, on the average from $8.5 \mathrm{~m}^{2}$ to $7.1 \mathrm{~m}^{2}$. Marini (2002) reported that trees bear the most valuable fruits when the crown is at the height of 1.2-1.5 m, but also at the height of up to $2.4 \mathrm{~m}$. Trees higher than $3.3 \mathrm{~m}$ give the greatest yield from an individual tree, but the costs of tree pruning, thinning of fruit buds, spraying and fruit harvest are higher. It is assumed (Marini 2002) that the most economical tree height is $2.1-2.7 \mathrm{~m}$ and, therefore, the purpose of tree pruning carried out every year should be aimed, among others, at the decreasing of tree height (Tab. 1).

Table 1. Growth of peach and nectarine trees after regeneration pruning, a year after pruning, autumn 2006

\begin{tabular}{|c|c|c|c|}
\hline Cultivar & Control & Trees pruned & Mean \\
\hline \multicolumn{4}{|c|}{ Tree crown height (m) } \\
\hline 'Harnaś' & $4.0 \mathrm{~d}^{*}$ & $2.7 \mathrm{a}$ & $3.3 \mathrm{c}$ \\
\hline 'Reliance' & $3.5 \mathrm{c}$ & $2.5 \mathrm{a}$ & $3.0 \mathrm{ab}$ \\
\hline 'Vinegold' & $3.1 \mathrm{~b}$ & $2.6 \mathrm{a}$ & $3.1 \mathrm{~b}$ \\
\hline 'Early Blaze' & $3.6 \mathrm{c}$ & $2.6 \mathrm{a}$ & $2.8 \mathrm{a}$ \\
\hline Mean & $3.5 \mathrm{~b}$ & $2.6 \mathrm{a}$ & \\
\hline \multicolumn{4}{|c|}{ Tree crown projection $\left(\mathrm{m}^{2}\right)$} \\
\hline 'Harnaś' & $7.6 \mathrm{ab}$ & $7.5 \mathrm{ab}$ & $7.5 \mathrm{a}$ \\
\hline 'Reliance' & $9.0 \mathrm{bc}$ & $6.5 \mathrm{a}$ & $7.8 \mathrm{a}$ \\
\hline 'Vinegold' & $7.4 \mathrm{ab}$ & $7.6 \mathrm{ab}$ & $7.5 \mathrm{a}$ \\
\hline 'Early Blaze' & $9.9 \mathrm{c}$ & $6.9 \mathrm{a}$ & $8.4 \mathrm{a}$ \\
\hline Mean & $8.5 \mathrm{~b}$ & $7.1 \mathrm{a}$ & \\
\hline \multicolumn{4}{|c|}{$\operatorname{TCSA}\left(\mathrm{cm}^{2}\right)^{* *}$} \\
\hline 'Harnaś' & $58.3 \mathrm{~d}$ & $71.3 \mathrm{e}$ & $64.8 \mathrm{~b}$ \\
\hline 'Reliance' & $45.9 \mathrm{bc}$ & $37.0 \mathrm{~b}$ & $41.5 \mathrm{a}$ \\
\hline 'Vinegold' & $44.8 \mathrm{bc}$ & $42.3 \mathrm{bc}$ & $43.5 \mathrm{a}$ \\
\hline 'Early Blaze' & $48.4 \mathrm{c}$ & $26.5 \mathrm{a}$ & $37.4 \mathrm{a}$ \\
\hline Mean & $49.3 \mathrm{~b}$ & $44.3 \mathrm{a}$ & \\
\hline \multicolumn{4}{|c|}{ TCSA spring - autumn $\left(\mathrm{cm}^{2}\right)$} \\
\hline 'Harnaś' & $5.0 \mathrm{bc}$ & $10.0 \mathrm{~d}$ & $7.5 \mathrm{c}$ \\
\hline 'Reliance' & $3.4 \mathrm{ab}$ & $2.9 \mathrm{a}$ & $3.2 \mathrm{a}$ \\
\hline 'Vinegold' & $5.9 \mathrm{c}$ & $4.9 \mathrm{bc}$ & $5.4 \mathrm{~b}$ \\
\hline 'Early Blaze' & $6.1 \mathrm{c}$ & $2.9 \mathrm{a}$ & $4.5 \mathrm{~b}$ \\
\hline Mean & $5.1 \mathrm{a}$ & $5.2 \mathrm{a}$ & \\
\hline
\end{tabular}


On the pruned trees in the discussed experiment, a greater number of one-yearold longshoots, which are valuable for future fruiting, developed in the central part of the crowns, with a diameter greater than $0.5 \mathrm{~cm}$, as compared with the nonpruned control trees. Depending on the growth character of the studied tree cultivars on the pruned trees, 5-8 longshoots developed (mean number: 6.7), while on the control trees, only 2-6 longshoots (mean number: 4.0) appeared. The longshoots on the pruned trees were also significantly longer, and they reached up to $73 \mathrm{~cm}$ in length, while on the control trees, their length showed on the average only $43 \mathrm{~cm}$. The total length of longshoots on the studied pruned trees was significantly greater than on the control ones, and they were $4.8 \mathrm{~m}$ and $2.0 \mathrm{~m}$, respectively (Tab. 2). There were no significant differences between the studied cultivars. As reported by many authors (Mika 1998, Marini 2002, Radajewska 2005), longshoots of 30-60 cm length are the most productive because they produce the greatest number of strong, valuable flower buds. Shorter shoots create buds that are too weak to produce valuable fruits. The thickness of tree trunk crosssectional areas of the control trees was greater in the first two years after pruning than that of the pruned trees (Tabs 1 and 3), but in the third year after pruning, the differences were equalized (Tab. 5).

Table 2. Longshoot characteristics of peach and nectarine trees after regeneration pruning, a year after pruning, autumn 2006

\begin{tabular}{|c|c|c|c|}
\hline Cultivar & Control & Trees pruned & Mean \\
\hline \multicolumn{4}{|c|}{ Number of shoots with diameter $\geq 0.5 \mathrm{~cm}$} \\
\hline 'Harnaś' & $3.8 a b^{*}$ & $4.8 \mathrm{bc}$ & $4.3 \mathrm{a}$ \\
\hline 'Reliance' & $1.7 \mathrm{a}$ & $7.8 \mathrm{~d}$ & $4.8 \mathrm{a}$ \\
\hline 'Vinegold' & $6.0 \mathrm{bcd}$ & $7.3 \mathrm{~cd}$ & $6.7 \mathrm{~b}$ \\
\hline 'Early Blaze' & $4.7 \mathrm{a}$ & $6.8 \mathrm{~cd}$ & $5.8 \mathrm{ab}$ \\
\hline Mean & $4.0 \mathrm{a}$ & $6.7 \mathrm{~b}$ & \\
\hline \multicolumn{4}{|c|}{ Mean length of shoots with diameter $\geq 0.5 \mathrm{~cm}(\mathrm{~cm})$} \\
\hline 'Harnaś' & $42.5 \mathrm{a}$ & $83.2 \mathrm{~b}$ & $62.8 \mathrm{a}$ \\
\hline 'Reliance' & 33.9 a & $69.3 \mathrm{~b}$ & $51.6 \mathrm{a}$ \\
\hline 'Vinegold' & $47.9 \mathrm{a}$ & $70.7 \mathrm{~b}$ & $59.3 \mathrm{a}$ \\
\hline 'Early Blaze' & $48.3 \mathrm{a}$ & $67.3 \mathrm{~b}$ & $57.8 \mathrm{a}$ \\
\hline Mean & $43.1 \mathrm{a}$ & $72.6 \mathrm{~b}$ & \\
\hline \multicolumn{4}{|c|}{ Total length of shoots with diameter $\geq 0.5 \mathrm{~cm}(\mathrm{~m})$} \\
\hline 'Harnaś' & $2.0 \mathrm{ab}$ & $4.0 \mathrm{~cd}$ & $3.0 \mathrm{a}$ \\
\hline 'Reliance' & $0.9 \mathrm{a}$ & $5.4 \mathrm{~d}$ & $3.2 \mathrm{a}$ \\
\hline 'Vinegold' & $2.9 \mathrm{bc}$ & $5.0 \mathrm{~d}$ & $4.0 \mathrm{a}$ \\
\hline 'Early Blaze' & $2.2 \mathrm{ab}$ & $4.6 \mathrm{~d}$ & $3.4 \mathrm{a}$ \\
\hline Mean & $2.0 \mathrm{a}$ & $4.8 \mathrm{~b}$ & \\
\hline
\end{tabular}

*Explanations: see Table 1 
Table 3. Growth of peach and nectarine trees after regeneration pruning, two years after pruning, autumn 2007

\begin{tabular}{|c|c|c|c|}
\hline Cultivar & Control & Trees pruned & Mean \\
\hline \multicolumn{4}{|c|}{ Tree crown projection $\left(\mathrm{m}^{2}\right)$} \\
\hline 'Harnaś' & $9.5 \mathrm{a}^{*}$ & $8.8 \mathrm{a}$ & $9.2 \mathrm{a}$ \\
\hline 'Reliance' & $8.9 \mathrm{a}$ & $8.1 \mathrm{a}$ & $8.5 \mathrm{a}$ \\
\hline 'Vinegold' & $7.9 \mathrm{a}$ & $7.6 \mathrm{a}$ & $7.8 \mathrm{a}$ \\
\hline 'Early Blaze' & $8.8 \mathrm{a}$ & $7.1 \mathrm{a}$ & $8.0 \mathrm{a}$ \\
\hline Mean & $8.8 \mathrm{a}$ & $7.9 \mathrm{a}$ & \\
\hline \multicolumn{4}{|c|}{$\operatorname{TCSA}\left(\mathrm{cm}^{2}\right) * *$} \\
\hline 'Harnaś' & $73.5 \mathrm{bc}$ & $80.0 \mathrm{c}$ & $76.7 \mathrm{~b}$ \\
\hline 'Reliance' & $65.2 \mathrm{abc}$ & $47.7 \mathrm{a}$ & $56.4 \mathrm{a}$ \\
\hline 'Vinegold' & $55.3 \mathrm{ab}$ & $54.5 \mathrm{a}$ & $54.9 \mathrm{a}$ \\
\hline 'Early Blaze' & $74.8 \mathrm{c}$ & $50.8 \mathrm{a}$ & $62.8 \mathrm{a}$ \\
\hline Mean & $67.2 \mathrm{~b}$ & $58.2 \mathrm{a}$ & \\
\hline
\end{tabular}

Table 4. Longshoot characteristics of peach and nectarine trees after regeneration pruning, two years after pruning, autumn 2007

\begin{tabular}{|c|c|c|c|}
\hline Cultivar & Control & Trees pruned & Mean \\
\hline \multicolumn{4}{|c|}{ Number of shoots with diameter $\geq 0.5 \mathrm{~cm}$} \\
\hline 'Harnaś' & $4.8 \mathrm{~cd}^{*}$ & $4.3 \mathrm{bc}$ & $4.6 \mathrm{~b}$ \\
\hline 'Reliance' & $4.3 \mathrm{bc}$ & $4.5 \mathrm{bcd}$ & $4.4 \mathrm{~b}$ \\
\hline 'Vinegold' & $4.3 \mathrm{bc}$ & $5.0 \mathrm{~d}$ & $4.7 \mathrm{~b}$ \\
\hline 'Early Blaze' & $3.7 \mathrm{a}$ & $4.2 \mathrm{ab}$ & $3.9 \mathrm{a}$ \\
\hline Mean & $4.3 \mathrm{a}$ & $4.5 \mathrm{a}$ & \\
\hline \multicolumn{4}{|c|}{ Mean length of shoots with diameter $\geq 0.5 \mathrm{~cm}(\mathrm{~cm})$} \\
\hline 'Harnaś' & $35.8 \mathrm{ab}$ & $50.9 \mathrm{~d}$ & $43.4 \mathrm{~b}$ \\
\hline 'Reliance' & $32.8 \mathrm{a}$ & $43.8 \mathrm{c}$ & $38.3 \mathrm{a}$ \\
\hline 'Vinegold' & $29.4 \mathrm{a}$ & $42.6 \mathrm{bc}$ & $35.5 \mathrm{a}$ \\
\hline 'Early Blaze' & $31.4 \mathrm{a}$ & $41.0 \mathrm{bc}$ & $36.2 \mathrm{a}$ \\
\hline Mean & $32.4 \mathrm{a}$ & $44.3 \mathrm{~b}$ & \\
\hline \multicolumn{4}{|c|}{ Total length of shoots with diameter $\geq 0.5 \mathrm{~cm}(\mathrm{~m})$} \\
\hline 'Harnaś' & $1.7 \mathrm{~b}$ & $2.1 \mathrm{c}$ & $1.9 \mathrm{c}$ \\
\hline 'Reliance' & $1.2 \mathrm{a}$ & $2.0 \mathrm{bc}$ & $1.6 \mathrm{ab}$ \\
\hline 'Vinegold' & $1.2 \mathrm{a}$ & $2.2 \mathrm{c}$ & $1.7 \mathrm{bc}$ \\
\hline 'Early Blaze' & $1.1 \mathrm{a}$ & $1.6 \mathrm{~b}$ & $1.4 \mathrm{a}$ \\
\hline Mean & $1.3 \mathrm{a}$ & $2.0 \mathrm{~b}$ & \\
\hline
\end{tabular}

*Explanations: see Table 1

In the successive years, the projection of the pruned trees was smaller than that of the non-pruned control trees (Tabs 3 and 5). In the second year after pruning, there was still the tendency towards the development of longer longshoots (valuable for fruiting), with a diameter greater than $0.5 \mathrm{~cm}$. Differences in the total length of the longshoots frequently appeared on selected branches of the studied tree cultivars (Tab. 4). 
Table 5. Growth of peach and nectarine trees after regeneration pruning, three years after pruning, autumn 2008

\begin{tabular}{lccc}
\hline Cultivar & Control & Trees pruned & Mean \\
\hline & Tree crown projection $\left(\mathrm{m}^{2}\right)$ & \\
\hline 'Harnaś' & $8.3 \mathrm{~cd} *$ & $7.8 \mathrm{bc}$ & $8.0 \mathrm{~b}$ \\
'Reliance' & $9.5 \mathrm{~d}$ & $6.6 \mathrm{ab}$ & $8.0 \mathrm{~b}$ \\
'Vinegold' & $7.9 \mathrm{bc}$ & $6.3 \mathrm{a}$ & $7.1 \mathrm{a}$ \\
'Early Blaze' & $8.6 \mathrm{~cd}$ & $6.7 \mathrm{ab}$ & $7.7 \mathrm{ab}$ \\
\hline Mean & $8.6 \mathrm{~b}$ & $6.9 \mathrm{a}$ \\
\hline \multicolumn{4}{c}{ TCSA $\left(\mathrm{cm}^{2}\right)^{* *}$} \\
'Harnaś' & $81.2 \mathrm{bc}$ & $90.3 \mathrm{c}$ & $85.7 \mathrm{~b}$ \\
'Reliance' & $69.4 \mathrm{ab}$ & $56.7 \mathrm{a}$ & $63.0 \mathrm{a}$ \\
'Vinegold' & $61.3 \mathrm{ab}$ & $65.2 \mathrm{ab}$ & $63.2 \mathrm{a}$ \\
'Early Blaze' & $81.3 \mathrm{bc}$ & $56.7 \mathrm{a}$ & $69.0 \mathrm{a}$ \\
\hline Mean & $73.3 \mathrm{a}$ & $67.2 \mathrm{a}$ & \\
****Explanations: see Table 1 & & &
\end{tabular}

In the second year after pruning, spring ground frost destroyed the flowers and fruit buds and only single fruits were harvested. In the third year after pruning, the trees bloomed very abundantly and set fruits, therefore a thinning was necessary. The yield was high and in most cases, it was equal independent of the tree pruning method, giving up to $18-19 \mathrm{~kg}$ per tree. Differences occurred only between the particular cultivars where the yield oscillated between 11 and $25 \mathrm{~kg}$ per tree. The best yielding was shown by 'Vinegold' - over $24 \mathrm{~kg}$, then followed 'Harnaś' $-21 \mathrm{~kg}$, while the poorest yield was obtained from 'Reliance' - about $11 \mathrm{~kg}$ (Figs 2, 3 and 4).

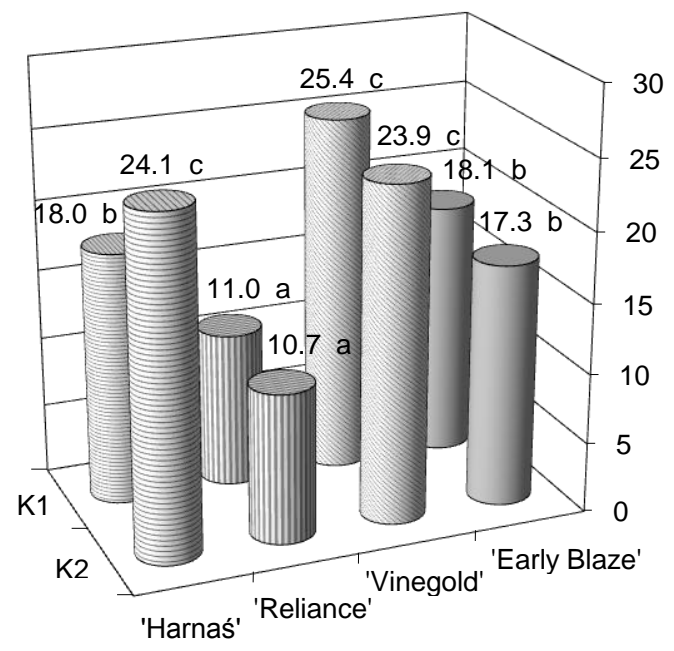
$\mathrm{K} 1$ - control
$\mathrm{K} 2$ - trees pruned at $1.5 \mathrm{~m}$ and shortening branches

Figure 2. Effect of pruning method on cultivar yielding of peaches and nectarine in $2008\left(\mathrm{~kg}^{\mathrm{r}} \mathrm{e}^{-1}\right)$ 

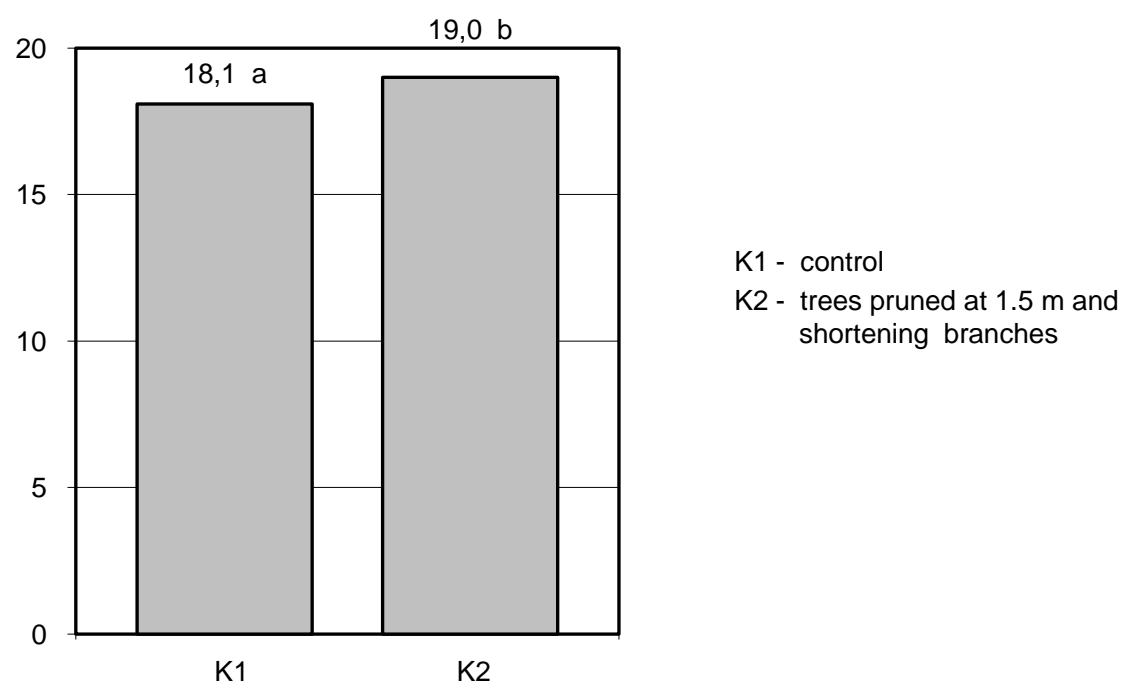
shortening branches

Figure 3. Effect of pruning method on mean yield of peaches and nectarine in $2008\left(\mathrm{~kg} \mathrm{tree}^{-1}\right)$

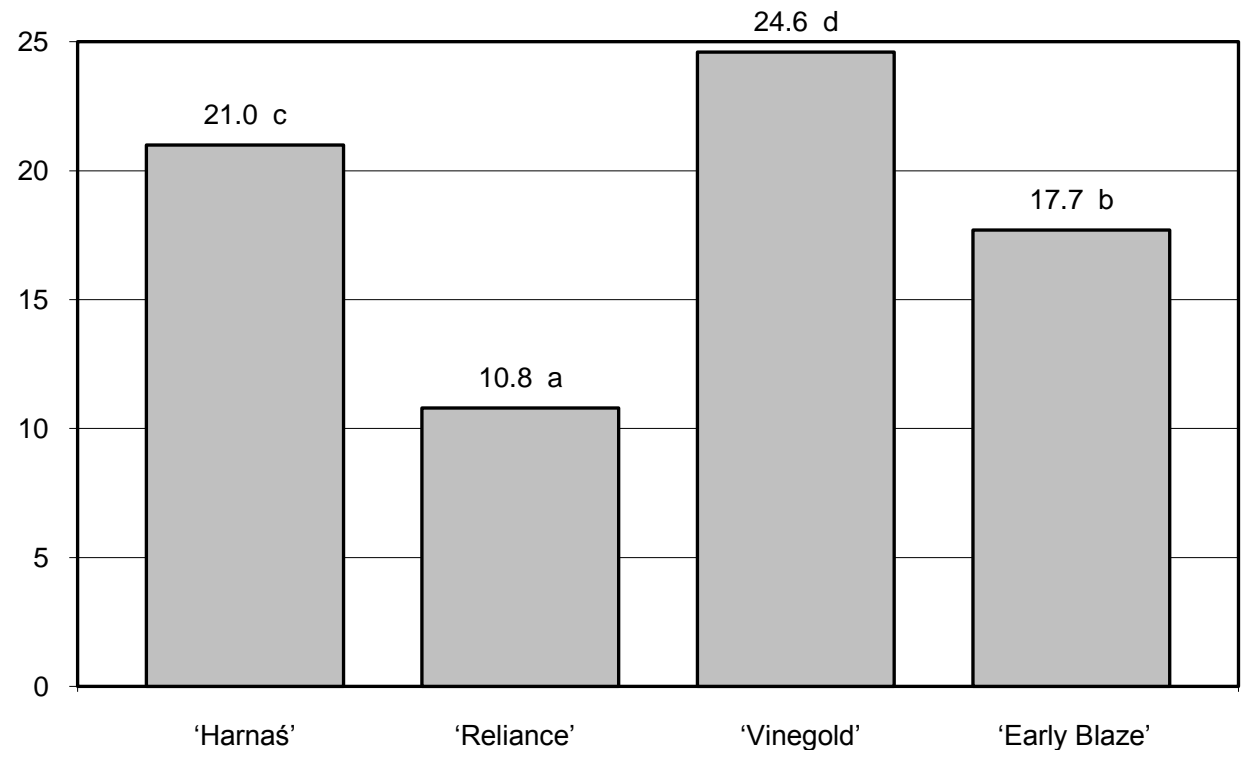

Figure 4. Mean yield of peaches and nectarine cultivars in $2008\left(\mathrm{~kg} \mathrm{tree}^{-1}\right)$ 


\section{CONCLUSIONS}

1. Intensive pruning of trees damaged by frost together with their high fertilization caused a very strong compensating growth directly after pruning.

2. Smaller crown projections of pruned trees remained for several years after treatment.

3. The tree crown fruit bearing zone decreased by pruning was compensated by the more valuable and productive thick and long longshoots, with a diameter greater than $0.5 \mathrm{~cm}$.

4. Properly performed intensive pruning of trees did not decrease the yield in the third year, in comparison with the non-pruned control trees.

\section{REFERENCES}

DUDZIŃSKI F., HoŁUBOwICZ T., 1985. Wpływ cięcia i nawożenia na regenerację i plonowanie brzoskwiń odmiany Siewka Rakoniewicka. Roczn. AR w Poznaniu 66: 89-99.

MARINI R.P., 1984. Vegetative growth of peach trees following three pruning treatments. Hort. Sci. 146: 287-292.

MARINI R.P., 2002. Pruning peach trees. Hortic. 422-020.

MiKA A., 1998. Cięcie drzew i krzewów owocowych. PWRiL, Warszawa: pp. 203.

MorgaŚ H., 2006. Regeneracja zimowych uszkodzeń drzew brzoskwini w zależności od sposobu cięcia. XLIV Ogólnopol. Nauk. Konf. Sadown.: 109.

NORTON M., 2002. Fruit wood rejuvenation by reducing tree height and shoot removal. Acta Hort. 592: 401-403.

RADAJEWSKA B., 1989. Wpływ cięcia odmładzającego na regenerację i przezimowanie drzew brzoskwiń 'Siewki Rakoniewickiej' i 'Siewki Jerzykowskiej'. Roczn. AR w Poznaniu, CCII: 163-176.

RADAJEWSKA B., 2005. Brzoskwinia, nektaryna, twardka i morela. PWRiL, Poznań: pp. 118.

RADAJEWSKA B., SzKLARZ M., 2006. Uszkodzenia mrozowe brzoskwiń i moreli w Wielkopolsce. Sad Nowoczesny 4: 14-15. 


\section{WZROST I PLONOWANIE DRZEW BRZOSKWINI I NEKTARYNY PO INTENSYWNYM CIĘCIU REGENERACYJNYM}

Streszczenie: Badania prowadzono w latach 2006-2008 w Przybrodzie koło Poznania. Przedmiotem badań były 7-letnie drzewa brzoskwini 'Harnaś, 'Reliance' i 'Vinegold' oraz nektaryny 'Early Blaze', silnie uszkodzone przez mróz w okresie zimy 2005/2006. W maju 2006 przeprowadzono intensywne cięcie regeneracyjne drzew. Uwzględniono dwie kombinacje: 1. Kontrolna; drzew nie cięto, przeprowadzono tylko cięcie sanitarne; 2. Drzewa przycięto na wysokość $1,5 \mathrm{~m}, \mathrm{z}$ pozostawieniem wyrastających poniżej pędów. Cięcie drzew wywołało obfitsze aniżeli na drzewach kontrolnych wyrastanie każdego roku w środkowej partii koron, wartościowych dla owocowania długopędów o średnicy $>0,5 \mathrm{~cm}$. W drugim roku po cięciu drzew przymrozki wiosenne zniszczyły kwiaty i zawiązki owoców, zebrano tylko pojedyncze owoce. W trzecim roku po cięciu drzewa bardzo obficie kwitly i zawiązały owoce, dlatego wymagały przerzedzania. Plon był wysoki i najczęściej wyrównany, niezależnie od sposobów cięcia drzew i wynosił 18-19 kg na drzewo. Różnice zaznaczyły się tylko między odmianami, plon wahał się od 11-25 kg na drzewo. Najlepiej plonowała odmiana 'Vinegold' (ponad $24 \mathrm{~kg}$ ), następnie 'Harnaś' (21 kg), a najsłabiej 'Reliance' (około $11 \mathrm{~kg}$ ). 